\title{
Role of Surfactant Protein D in Experimental Otitis Media
}

\author{
Osama Abdel-Razek ${ }^{\mathrm{a}}$ Tianyi Liu $^{\mathrm{a}}$ Xinghua Chen ${ }^{\mathrm{a}}$ Qiushi Wang ${ }^{\mathrm{a}}$ \\ Gautam Vanga a Guirong Wang ${ }^{a, b}$ \\ ${ }^{a}$ Department of Surgery, SUNY Upstate Medical University, Syracuse, NY, USA; bepartment of Microbiology and \\ Immunology, SUNY Upstate Medical University, Syracuse, NY, USA
}

\section{Keywords \\ Haemophilus influenzae - Nuclear factor kappa B signaling · NLRP3 activation - Otitis media · Surfactant protein D}

\begin{abstract}
Surfactant protein D (SP-D) is a C-type collectin and plays an important role in innate immunity and homeostasis in the lung. This study studied SP-D role in the nontypeable Haemophilus influenzae (NTHi)-induced otitis media (OM) mouse model. Wild-type C57BL/6 (WT) and SP-D knockout (KO) mice were used in this study. Mice were injected in the middle ear (ME) with $5 \mu \mathrm{L}$ of NTHi bacterial solution $\left(3.5 \times 10^{5}\right.$ CFU/ear) or with the same volume of sterile saline (control). Mice were sacrificed at 3 time points, days 1, 3, and 7, after treatment. We found SP-D expression in the Eustachian tube (ET) and ME mucosa of WT mice but not in SP-D KO mice. After infection, SP-D KO mice showed more intense inflammatory changes evidenced by the increased mucosal thickness and inflammatory cell infiltration in the ME and ET compared to WT mice $(p<0.05)$. Increased bacterial colony-forming units and cytokine (IL- 6 and IL-1 $\beta$ ) levels in the ear washing fluid of infected SP-D KO mice were compared to infected WT mice. Molecular analysis revealed higher levels of NF-KB
\end{abstract}

and NLRP3 activation in infected SP-D KO compared to WT mice $(p<0.05)$. In vitro studies demonstrated that SP-D significantly induced NTHi bacterial aggregation and enhanced bacterial phagocytosis by macrophages $(p<0.05)$. Furthermore, human ME epithelial cells showed a dose-dependent increased expression of NLRP3 and SP-D proteins after LPS treatment. We conclude that SP-D plays a critical role in innate immunity and disease resolution through enhancing host defense and regulating inflammatory NF-KB and NLRP3 activation in experimental OM mice.

(c) 2021 The Author(s).
Published by S. Karger AG, Basel

\section{Introduction}

Otitis media $(\mathrm{OM})$ is the leading cause of bacterial infections and antibiotic prescriptions in early childhood [1-5]. About $60-80 \%$ of children will have at least one episode of OM during their first year of life [6]. The global health burden of OM is heavy, about 709 million new cases per year. Thirty-one million children will develop chronic suppurative OM resulting in about 21,000 deaths every year from complications [7]. OM is also the primary indication of pressure-equalizing tube insertion, which
(C) 2021 The Author(s)

Published by S. Karger AG, Basel

This is an Open Access article licensed under the Creative Commons Attribution-NonCommercial-4.0 International License (CC BY-NC) (http://www.karger.com/Services/OpenAccessLicense), applicable to the online version of the article only. Usage and distribution for commercial purposes requires written permission.
Guirong Wang

Department of Surgery, UH Room 8715

SUNY Upstate Medical University, 750 E. Adams St.

Syracuse, NY 13210 (USA)

wangg@upstate.edu 
is the most common surgical operation performed in children [8].

Both viral and bacterial agents can cause OM. Nontypeable Haemophilus influenzae (NTHi) is one of the most common infectious pathogens in OM [9-11]. The innate immune response plays a significant role in $\mathrm{OM}$ susceptibility in early life before the development of specific immunity [6]. Innate immunity effectors include antimicrobial peptides, host defense proteins, cytokines, and chemokines that attract phagocytes to the affected site and enhance their phagocytic and microbicidal capacity [12]. Similar to the respiratory epithelium, the middle ear (ME) epithelium is composed of ciliated cells, secretory and nonsecretory cells, and basal cells. Secretory cells are responsible for producing mucins and various antimicrobial proteins such as lactotransferrin, lysozyme, defensins, and surfactants. The epithelium, along with its secretions, is involved in maintaining homeostasis and sterility within the middle ear cavity (MEC). Epithelial remodeling, characterized by mucociliary metaplasia and infiltration of the MEC with inflammatory cells, is a common feature of OM [13]. The availability of human middle ear epithelial cell line (HMEEC-1) can help in studying the normal biology of the ME epithelium, as well as to enhance our understanding of the molecular mechanisms involved in the pathogenesis of human OM, which will facilitate our efforts to find effective preventative and therapeutic drugs for OM [14]. Interleukin- $1 \beta$ (IL- $1 \beta)$ is an important cytokine in triggering the inflammatory and antibacterial response. Caspase- 1 activates IL- $1 \beta$ from its precursor (pro-IL-1 $\beta$ ). Procaspase- 1 is a part of the complex constituting NLRP3 inflammasome, which is induced by various inflammation-inducing stimuli through TLRs and nuclear factor kappa B (NF-кB) [15].

Surfactant protein D (SP-D) is a hydrophilic and multimeric protein that belongs to the family of C-type lectins, or collectins, and contributes to the innate immune response of mucosal surfaces of the body [16]. SP-D is synthesized by alveolar type II cells and secreted into alveolar spaces in the lung [17]. Mice lacking the SP-D gene have a progressive accumulation of surfactant lipids, SP-A, and SP-B in the alveolar space. By the age of 8 weeks, the alveolar phospholipid pool becomes higher than wild-type C57BL/6 (WT) littermates. There was also more accumulation of alveolar macrophages in the SP-D knockout (KO) mice, and many macrophages were both multinucleated and foamy in appearance [18]. The lungs of SP-D KO mice showed a chronic low-grade inflammation characterized by alveolar lipidosis and the development of pulmonary fibrosis and emphysema [19]. Several studies have shown that SP-D is also expressed in extrapulmonary organs, including the tongue, oral epithelium, and ME $[20,21]$. SP-D is expressed in the normal human and porcine Eustachian tube (ET) $[16,22,23]$. Uncomplicated acute OM often resolves within days, even without antibiotic treatment. This is a brief period for the development of specific immunity to play a significant role in the resolution of infection. This implicates the innate immune system, which is activated without prior sensitization, as the major effector of OM resolution [24]. In the absence of specific antimicrobial antibodies, SP-D functions in the first line of defense as a pattern recognition receptor and binds to and increases the phagocytosis of Streptococcus pneumoniae and $H$. influenzae, the most common pathogens in acute OM [6, $22,25]$.

SP-D plays an important role in the innate immune response through interactions with pathogens or interaction with the host cells. SP-D helps in the opsonization of pathogens [26-28]. The agglutination of target pathogens provides the first line of defense that can then be enhanced by killing and clearance mechanisms mediated by phagocytic cells that carry receptors for SP-A and SP-D [29]. Wu et al. [30] presented data indicating that SP-D is an antimicrobial protein that directly inhibits the proliferation of Gram-negative bacteria in a macrophage- and the aggregation-independent manner by increasing the permeability of the microbial cell membrane. Although the role of SP-D in defense of the tubotympanum remains to be proven, it is likely that a deficiency in these molecules may contribute to the pathogenesis of OM [31]. Recently, we have demonstrated that SP-A contributes to the ME's innate immunity through enhancing bacterial phagocytosis and killing and modulation of inflammation of the ME mucosa in the OM murine model [32]. In this study, we have used our NTHi-induced OM model and genetically modified SP-D KO mice to examine the role of SP-D and the underlying cellular and molecular mechanisms in the pathogenesis of OM.

\section{Materials and Methods}

Mice

We used male and female 8-10-week-old WT mice and agematched SP-D KO mice with C57BL/6 background for this experiment. We bred the SP-D KO mice in the pathogen-free animal core facility at SUNY Upstate Medical University and initially purchased WT C57BL/6 mice from Jackson Laboratories (Bar Harbor, ME, USA) and bred them in the same animal core facility. All an- 
imal experiments and protocols were conducted following the guidelines of the Institutional Animal Care and Use Committee (IACUC), SUNY Upstate Medical University, National Institutes of Health guidelines on the use of laboratory animals, and those of "ARRIVE" on the use of laboratory animals. We followed up the mice for 7 days and sacrificed a group of mice on days 1,3 , and 7 .

\section{Bacterial Strain and Preparation}

Clinical isolates of NTHi 3655 strain were used for this study. We streaked bacteria from frozen stock with a sterile loop onto Chocolate Agar II plates. The plates were incubated at $37^{\circ} \mathrm{C}$ overnight in $5 \% \mathrm{CO}_{2}$ atmosphere. We picked 2 colonies and grew them in $5 \mathrm{~mL}$ of Brain Heart Infusion Broth (BHI) with Fildes Enrichment. Bacteria were spun down for $10 \mathrm{~min}$ at $9,000 \mathrm{rpm}$ at $4^{\circ} \mathrm{C}$. The bacterial pellet was resuspended in $1 \mathrm{~mL}$ of normal saline. The bacterial solution was adjusted to $\mathrm{OD}_{600}=0.6$ with normal saline. We used $5 \mu \mathrm{L}$ of a dilution of 1:100 of this solution for ME infection.

\section{Animal Surgery}

We anesthetized the mice by intraperitoneal injection with a combination of ketamine $(90 \mathrm{mg} / \mathrm{kg})$ and xylazine $(10 \mathrm{mg} / \mathrm{kg}$, i.e., $0.1 \mathrm{~mL} / 100-\mathrm{g}$ animal weight). The intensity of anesthesia was monitored by means of toe pinching using tweezers. We performed otomicroscopic examination for all mice before injection to ensure that tympanic membranes were normal and that no ME effusion was present. We used a 30-gauge needle to inject the bacterial solution into the anterior part of the mouse tympanic membrane. The infection group received $5 \mu \mathrm{L}$ of the bacterial solution, and the control group was injected with $5 \mu \mathrm{L}$ of normal saline into their MEs. Mice were sacrificed on days 1, 3, and 7 after injection of bacteria or saline. We washed the MEs with $200 \mu \mathrm{L}$ of normal saline, and we used the ME washes for cell counting and determination of bacterial colony-forming units (CFUs).

\section{Histological Analysis}

We removed mouse temporal bones immediately after sacrifice, fixed in $4 \%$ paraformaldehyde for $48 \mathrm{~h}$ followed by decalcification in Cal-Ex solution for $6 \mathrm{~h}$ and then $10 \%$ formaldehyde. After dehydration, we embedded specimens in paraffin, sectioned at a thickness of $4 \mu \mathrm{m}$, and stained with hematoxylin and eosin (H\&E) for histological examination [33].

\section{Bacterial CFUs and Inflammatory Cell Recruitment}

\section{Examination}

Ear wash with $200-\mu \mathrm{L}$ sterile saline was performed to collect samples for examination of the cellular contents and bacterial culture for determination of CFU count at different time points in WT and SP-D KO mice. Ten microliters were diluted 100 times, and $200 \mu \mathrm{L}$ were spread on Chocolate Agar plates and incubated overnight for CFU count. The remaining ear wash fluid was centrifuged at $250 \mathrm{~g}$ for $10 \mathrm{~min}$, and the pellets were resuspended in $200-\mu \mathrm{L}$ saline and were used to prepare slides to visualize the cellular component of the ear wash. We manually counted cell types in 5 randomly selected high-power fields $(\times 400)$. The numbers of neutrophils and macrophages comprising $\mathrm{ME}$ were calculated and used for comparing the cellular infiltration at different time points.

\section{Phagocytosis Study}

We used an in vitro assay to evaluate macrophage function. We incubated alveolar macrophages with viable NTHi bacteria to allow phagocytosis. Extracellular bacteria are then removed by rinsing with saline. After centrifugation and resuspension of the pellets, we used the cytospin for making the slides. We obtained alveolar macrophages from SP-D KO mice by bronchoalveolar lavage. We centrifuged $1 \mathrm{~mL}$ of bronchoalveolar lavage fluid at $250 \mathrm{~g}$ for $10 \mathrm{~min}$ and resuspended the pellet in $1 \mathrm{~mL}$ of DMEM media. The suspended cells were divided into 4 groups for the following phagocytosis assay. We stored NTHi strain 3655 at $-80^{\circ} \mathrm{C}$ in $\mathrm{BHI}$ with $20 \%$ glycerol. To prepare the inoculation, we streaked bacteria from the frozen stock onto a Chocolate Agar plate and incubated it overnight in $5 \% \mathrm{CO}_{2}$ atmosphere at $37^{\circ} \mathrm{C}$. We picked 2 colonies to grow in $5 \mathrm{~mL}$ of BHI with Fildes Enrichment overnight to reach $\mathrm{OD}_{600}=0.6$. Bacteria were spun down for $10 \mathrm{~min}$ at $9,000 \mathrm{rpm}\left(\right.$ at $\left.4^{\circ} \mathrm{C}\right)$. The bacterial pellet was resuspended in $1 \mathrm{~mL}$ of normal saline. For phagocytosis assay, 4 groups $(250 \mu \mathrm{L}$ of cell solution) of macrophages were included: (1) only macrophages (control); (2) macrophages plus SP-D (5 $\mu \mathrm{g} / \mathrm{mL})$; (3) macrophages plus cytochalasin $\mathrm{D}[2 \mu \mathrm{g} / \mathrm{mL}])$; and (4) macrophages plus SP-D $(5 \mu \mathrm{g} / \mathrm{mL})$ and cytochalasin D $(5 \mu \mathrm{g} /$ $\mathrm{mL})$. There was $5-\mu \mathrm{M} \mathrm{CaCl}$ in all tubes. Then, $10-\mu \mathrm{L}$ bacteria were added to each Eppendorf tube (final ratio 1:13 of cells to bacteria) and incubated for $60 \mathrm{~min}$ at $37^{\circ} \mathrm{C}$ with $5 \% \mathrm{CO}_{2}$. One milliliter of normal saline was added to each tube and centrifuged for $5 \mathrm{~min}$ at $150 \mathrm{~g}$. The fluid was removed, and the pellet was resuspended in $200-\mu \mathrm{L}$ saline and was pipetted into cytospin funnels to prepare the slides for visualization of the phagocytosis and to compare the effect of presence or absence of SP-D. After staining the slides, we randomly selected 100 macrophages per slide that were analyzed at $\times 1,000$ magnification. We calculated the phagocytic index (PI) as the percentage of bacteria-positive macrophages (cells that phagocytized at least one bacterium) multiplied by the average number of bacteria per bacteria-positive macrophage.

\section{Bacterial Aggregation Study}

We added SP-D at final concentrations of 10 and $20 \mu \mathrm{g} / \mathrm{mL}$ into bacteria solution of NTHi and added $\mathrm{CaCl}_{2}$ (final concentration at $2 \mu \mathrm{M}$ ) to each well. The mixed solution was incubated with the bacteria for $1 \mathrm{~h}$ at $37^{\circ} \mathrm{C}$ and then examined under the microscope to record the difference in bacterial aggregation in different concentrations of SP-D in comparison to control.

\section{Immunofluorescence Staining}

We used immunofluorescence to detect SP-D expression and the expression of NLRP3 in the ME and ET mucosa. In brief, following deparaffinization and antigen retrieval, sections were blocked using 10\% donkey serum (ab7475; Abcam Inc., Cambridge, MA, USA) for $60 \mathrm{~min}$ at room temperature and then incubated with anti-SP-D (1:200; gift from Dr. Wright; Duke University Medical Center, Durham, NC, USA), or anti-NLRP3 antibody (PA5-20838; Thermo Scientific) or anti-p-NF- $\kappa$ B p65 (\#3033; Cell Signaling Technology [CST], Boston, MA, USA) antibodies at $4^{\circ} \mathrm{C}$ overnight. For fluorescence visualization of primary antibodies, sections were stained with Alexa 488 (ab150073; Abcam Inc., Cambridge, MA, USA). Nuclei were counterstained with fluoroshield mounting medium with DAPI (ab 104139; Abcam Inc., Cambridge, MA, USA) for $15 \mathrm{~min}$, and the sections analyzed using a Nikon Eclipse TE2000-U microscope (Nikon Corporation, Tokyo, Japan). 


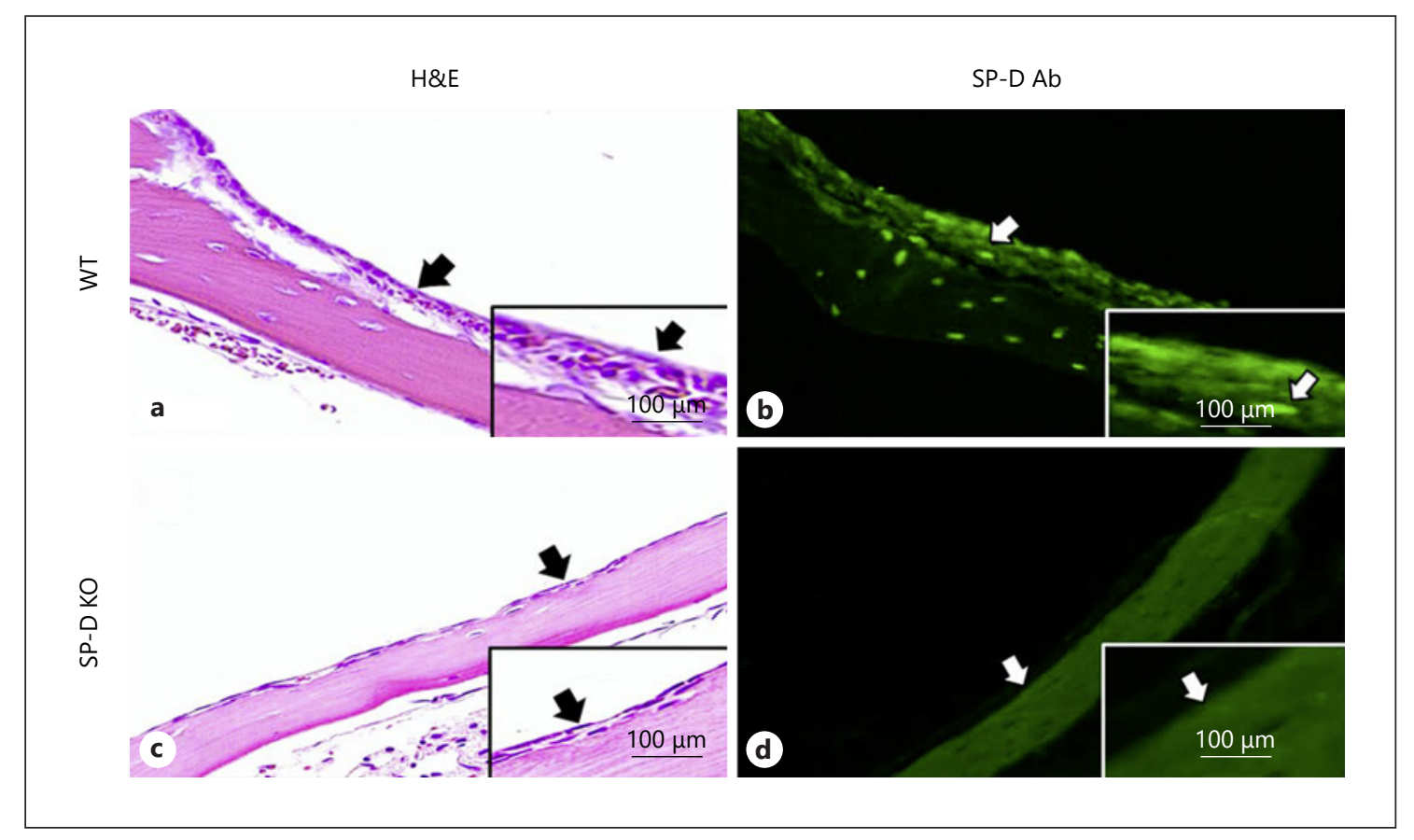

Fig. 1. SP-D expression in the ME mucosa of WT but not in SP-D KO mice: SP-D expression in the ME mucosa of WT and SP-D KO mice by immunofluorescence assay. a H\&E light microscopic histology of WT mouse ME mucosa. $\mathbf{b}$ Immunofluorescent staining of the same mouse. c Light microscopic histology of SP-D KO ME. d Im-

\section{RT-PCR Analysis}

Total RNA was prepared from mouse temporal bones stored at $-80^{\circ} \mathrm{C}$ by using 1 RNA-bee kit (Tel-Test, Friendswood, TX, USA). The ME tissues were homogenized with $0.5 \mathrm{~mL}$ of RNA-Bee RNA isolation solvent in 1.5-mL Eppendorf tube. Then, $0.1 \mathrm{~mL}$ of chloroform was added into the tube and mixed vigorously. Centrifugation was performed at $12,000 \mathrm{~g}$ for $15 \mathrm{~min}$ at $4^{\circ} \mathrm{C}$. The aqueous phase was transferred to a new tube, and $0.27 \mathrm{~mL}$ of isopropanol was added. After mixing by vortex, the solution was incubated for $20 \mathrm{~min}$ at room temperature and then centrifuged at $12,000 \mathrm{~g}$ and $4^{\circ} \mathrm{C}$ for $35 \mathrm{~min}$. The supernatant was discarded carefully, and the pellet was washed with $1 \mathrm{~mL}$ of $75 \%$ ethanol. After centrifuging at 7,500 $\mathrm{g}$ for $10 \mathrm{~min}$, the pellet was air-dried for $10 \mathrm{~min}$ and then dissolved in $30 \mu \mathrm{L}$ of DEPC water. The concentration was determined by NanoDrop machine (Thermo Fisher Scientific). Any DNA contamination in the RNA solution was removed by RQ1 RNase-free DNase (Cat. M6101; Promega). Two micrograms of total RNA of each sample were used to synthesize cDNA using M-MuLV reverse transcriptase (NEB). RT-PCR of NF- $\kappa$ B1 and NLRP3 was performed as described previously $[34,35]$. For NF- $\kappa B 1$, primer pair (forward, GAAATTCCTGATCCAGACAAAAAC; reverse, ATCACTTCAATGGCCTCTGTGTAG, 194-bp product) was used, and for NLRP3, primer pair (forward, AGAAGAGACCACGGCAGAAG; reverse, CCTTGGACCAGGTTCAGTGT) was used for RT-PCR amplification. We used ImageJ to quantitate the PCR bands at different time points. munofluorescence assay of the same mouse. No SP-D was detected in the ME mucosa. Green represents SP-D expression. Black arrows point to ME mucosa; white arrows point to cells expressing SP-D (b) and absence of expression (d) ( $n=5$ mice/group). SP-D, surfactant protein $\mathrm{D}$; ME, middle ear; WT, wild type; KO, knockout.

\section{Human Middle Ear Epithelial Cells and Culture}

HMEEC-1 is a human immortalized ME epithelial cell line described by Chun et al. [14], which was generously provided to us by Dr. Stephanie Val (Sheikh Zayed Institute for Pediatric Surgical Innovation, Washington, DC, USA). Cells were maintained in 1:1 of bronchial epithelial cell basal medium (Lonza, Walkersville, MD, USA) and DMEM (Thermo Fisher Scientific) and supplemented with the SingleQuots kit (Lonza) containing bovine pituitary extract, hydrocortisone, human epidermal growth factor, epinephrine, transferrin, insulin, tri-iodothyronine, retinoic acid, gentamycin, and amphotericin-B. We treated the cells with lipopolysaccharide (LPS) at a range of concentrations from 0 to $50 \mu \mathrm{g} /$ $\mathrm{mL}$ and incubated for $24 \mathrm{~h}$. Cells were deprived of SingleQuots $4 \mathrm{~h}$ before LPS challenge in bronchial epithelial basal medium/ DMEM [11]. We used Western blot to measure the expression of SP-D and NLRP3 in response to different doses of LPS.

\section{ELISA Assay}

The SP-D KO and WT mice were treated by the transtympanic injection of NTHi. Four to 6 mice per test were euthanized at 1 , 3 , or 7 days, respectively, and 2 tests were performed: IL- $1 \beta$ and IL-6. The control group has a transtympanic injection of sterile saline. MEs were washed with $200-\mu \mathrm{L}$ saline, and samples were taken from mice at every time point. We then measured concentrations of IL- $1 \beta$ and IL- 6 in ME wash samples by using enzymelinked immunosorbent assay (ELISA) kits (Invitrogen) according to each of the manufacturer's protocols. 


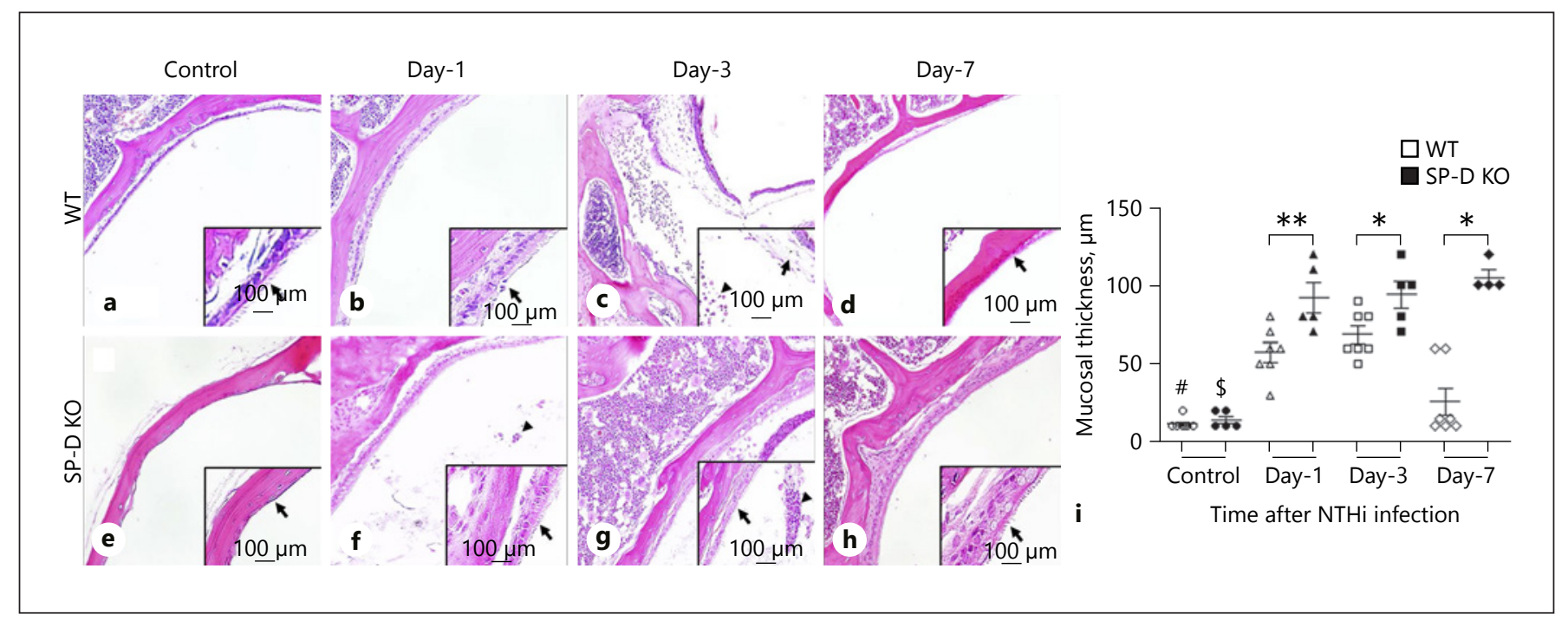

Fig. 2. Inflammatory changes in the MEs of SP-D KO and WT mice over different time points: ME response to NTHi in WT C57BL/6 mice (a-d) and SP-D KO mice (e-h). The ME of WT mice demonstrated inflammation and thickening of the ME mucosa on day 1 (b). By day 3 postinfection with NTHi, the ME cavities of WT mice were filled with inflammatory cells (c). By day 7, the ME mucosa looks normal (d). By day 1 after NTHi infection, SP-D KO mice had much more inflammatory cells in the ME cavity (f). By day 3 after infection, the MEs of SP-D KO mice showed increased numbers of inflammatory cells and a significantly increased mu- cosal thickness $(\mathbf{g})$ compared to infected WT mice $(p<0.05)$. Day 7 shows the persistence of inflammation in SP-D KO mice (h). Black arrows indicate mucosal thickening; arrowheads point to cellular infiltration. Statistical analysis of mucosal thickness is shown in the panel (i). \# indicates control versus infected WT, which is significant on days 1 and 3 but not on day 7. \$ indicates control versus infected SP-D KO mice, which is significant for all 3 time points. Original magnifications, $\times 100(n=5 \mathrm{mice} /$ group/ time point). SP-D, surfactant protein D; ME, middle ear; NTHi, nontypeable $H$. influenzae; WT, wild type; $\mathrm{KO}$, knockout.

\section{Statistical Analysis}

Data were expressed as means \pm SEM, and statistical analyses were performed using SigmaStat 3.5 (Jandel Scientific, San Rafael, CA, USA). Student's $t$ test or ANOVA test was performed to assess the statistical significance of differences. A $p$ value of $<0.05$ was considered statistically significant.

\section{Results}

\section{SP-D Is Expressed in the Eustachian Tube and ME} Mucosa of WT Mice

We used immunofluorescence staining to examine the expression of SP-D in the ME and ET mucosae of WT and SP-D KO mice. SP-D expression was detected in the ME and ET mucosae of WT but not in SP-D KO mice (Fig. 1).

\section{The More Intense and Prolonged Inflammatory \\ Response to NTHi in SP-D KO OM Compared to WT OM Mice}

To define the functional role of SP-D in the ME response to NTHi, we examined the inflammatory response to NTHi infection in the ME of SP-D KO mice in com- parison to that of WT mice. We used mucosal thickness as a way to measure the degree of inflammation in the ME. The ME mucosa undergoes inflammatory changes after NTHi infection. There is a significant swelling of the epithelial and supporting layers of the mucosa and considerable inflammatory cell infiltration in the MEC. In WT mice, these changes are most prominent 1-3 days after NTHi infection (Fig. 2b, c). ME mucosal resolution was completed by 7 days after infection (Fig. 2d). The MEs of SP-D KO mice also displayed mucosal thickening, and inflammatory cells infiltrate by days 1-3 (Fig. 2f, g, 3). However, the inflammatory reaction is more intense as we observed significantly increased mucosal thickness (Fig. 2i) compared to WT OM mice $(p<0.05)$ as well as inflammatory cellular infiltration. By day 7 , the inflammatory changes remained stronger in SP-D KO OM mice but not in WT OM mice, which had returned to the baseline (Fig. 2d, h).

\section{Neutrophil and Macrophage Recruitment in WT and SP-D KO OM Mice}

Increased neutrophils and macrophages, as well as a few lymphocytes, were observed in the middle ear wash 


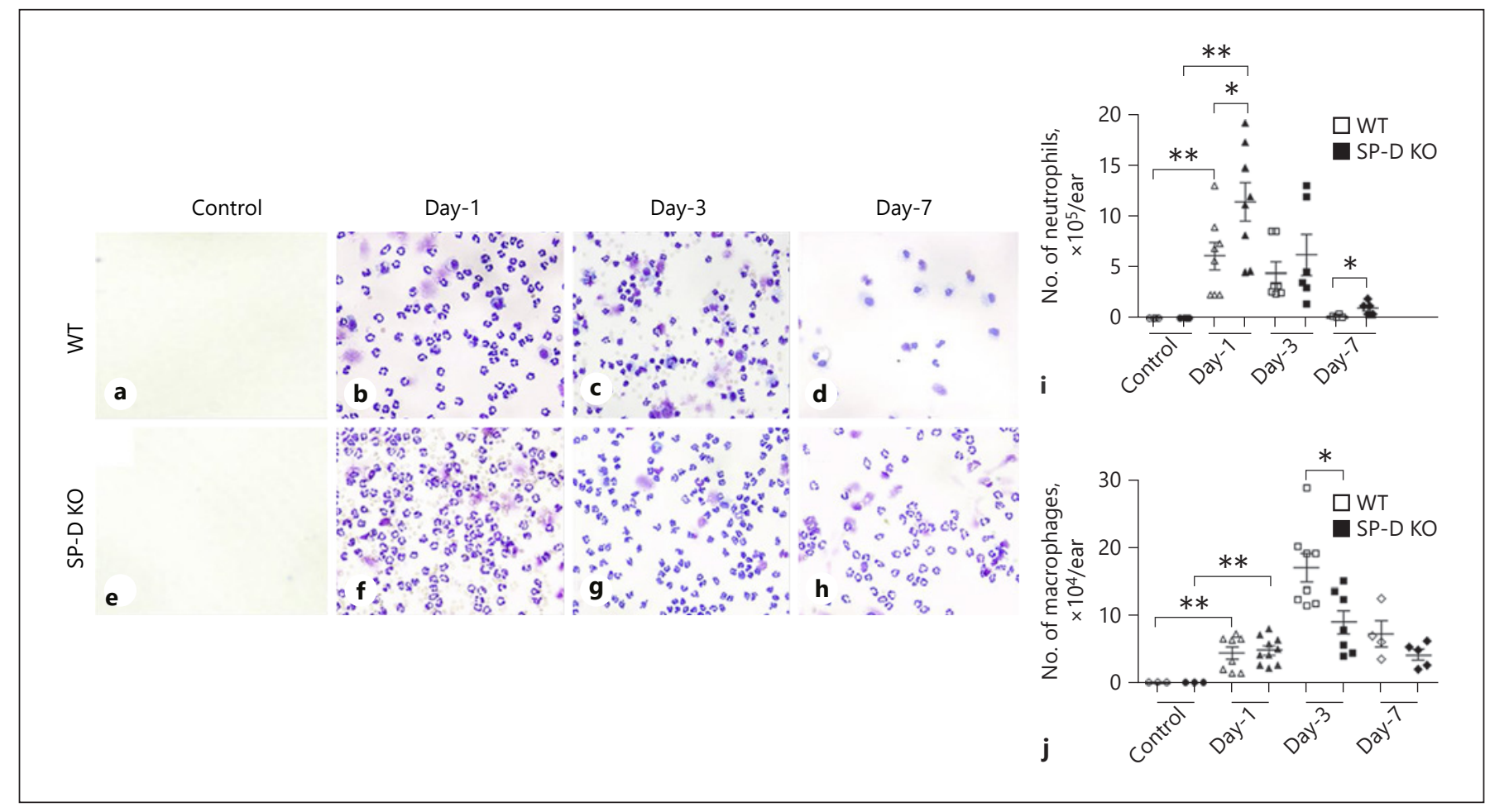

Fig. 3. Inflammatory cell recruitment in the MEs after NTHi inoculation: after NTHi infection, the MEs were washed with $200-\mu \mathrm{L}$ saline, and cytospin was used to prepare the slides. A representative panel of photos of inflammatory cells is shown (a-h). Neutrophil recruitment was noted to peak over the first day in WT mice (i). The number of neutrophils went down over the third day after NTHi inoculation, and by day 7, few neutrophils can be detected. In SP-D KO mice,

fluid (MEWF) after NTHi infection. Neutrophil recruitment was to peak over the first day in WT OM mice (Fig. 3). The number of neutrophils went down on day 3 after NTHi inoculation in WT OM mice. In SP-D KO OM mice, the pattern of neutrophil recruitment was significantly different from WT OM mice, increased neutrophils than in the first and the seventh days in SP-D KO OM mice compared to WT OM mice (Fig. 3). There is a predominance of neutrophils on day 1 with a few macrophages, but an increased percentage of macrophages were observed on day 3. Interestingly, the number of macrophages on the third day was significantly higher in the WT compared to the SP-D KO mice $(p<0.05)$. The lack of SP-D influenced the percentage of macrophages in the $\mathrm{ME}$ on the third day as macrophages comprised 3.4\% of the total number of cells in SP-D KO OM mice compared to $7 \%$ in WT OM mice, and on the seventh day, macrophages comprised $23 \%$ of the total number of cells in SP-D KO mice compared to $38 \%$ in WT mice. recruitment of neutrophils was significantly higher than in WT mice in the first and the seventh days. Day 1 showed a predominance of neutrophils with few macrophages, and day 3 showed an increased percentage of macrophages. Macrophage recruitment was significantly higher in WT than in SP-D KO mice on day $3(\mathbf{j})$. Original magnifications, $\times 400$. SP-D, surfactant protein D; ME, middle ear; NTHi, nontypeable $H$. influenzae; WT, wild type; KO, knockout.

\section{Bacterial CFUs from a Middle Ear Wash Fluid}

MEWF collected at different time points was used for bacterial culture and CFU count. The results showed a significant number of CFUs on day 1 but no difference in CFUs between WT and SP-D KO mice. However, a significant difference in CFUs between WT and SP-D KO mice was observed on day 3 (SP-D KO $>$ WT) $(p<0.05)$ (Fig. 4).

\section{Enhanced Bacterial Aggregation in the Presence of $S P-D$}

To examine the effect of SP-D in NTHi bacterial aggregation, purified SP-D protein (final concentration at 0 [control], 10, and $20 \mu \mathrm{g}$ of SP-D/mL) was added into NTHi bacterial solution in the presence of $2-\mu \mathrm{M} \mathrm{CaCl}{ }_{2}$. Bacterial aggregation was examined by using a light microscope after incubation for $1 \mathrm{~h}$ at $37^{\circ} \mathrm{C}$. The results showed the difference in bacterial aggregation in the presence and the absence of SP-D (Fig. 5). Many large bacte- 
Fig. 4. Bacterial CFUs from middle ear wash fluid: middle ear wash fluid from different time points was diluted with sterile saline and then cultured with Chocolate Agar plates and incubated at $37^{\circ} \mathrm{C}$ in $5 \%$ of $\mathrm{CO}_{2}$ overnight. CFUs were counted in the plates. The data indicated that there were significant bacterial CFUs on days 1 and 3 after infection. However, no difference in CFUs between WT and SP-D KO on day 1 was observed, while a significant difference existed between the 2 groups on day 3 (SP$\mathrm{D} \mathrm{KO}>\mathrm{WT})\left({ }^{*} p<0.05\right)(n=4$ mice/group/ time point). CFUs, colony-forming units; SP-D, surfactant protein D; WT, wild type; $\mathrm{KO}$, knockout.

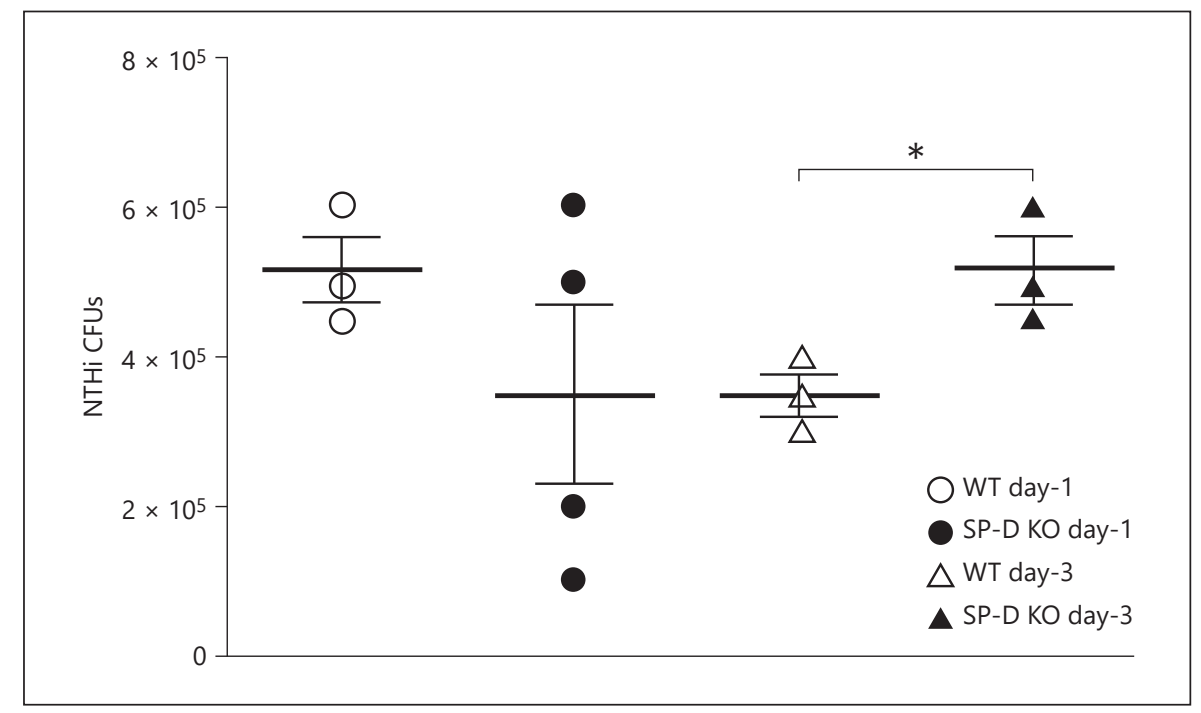

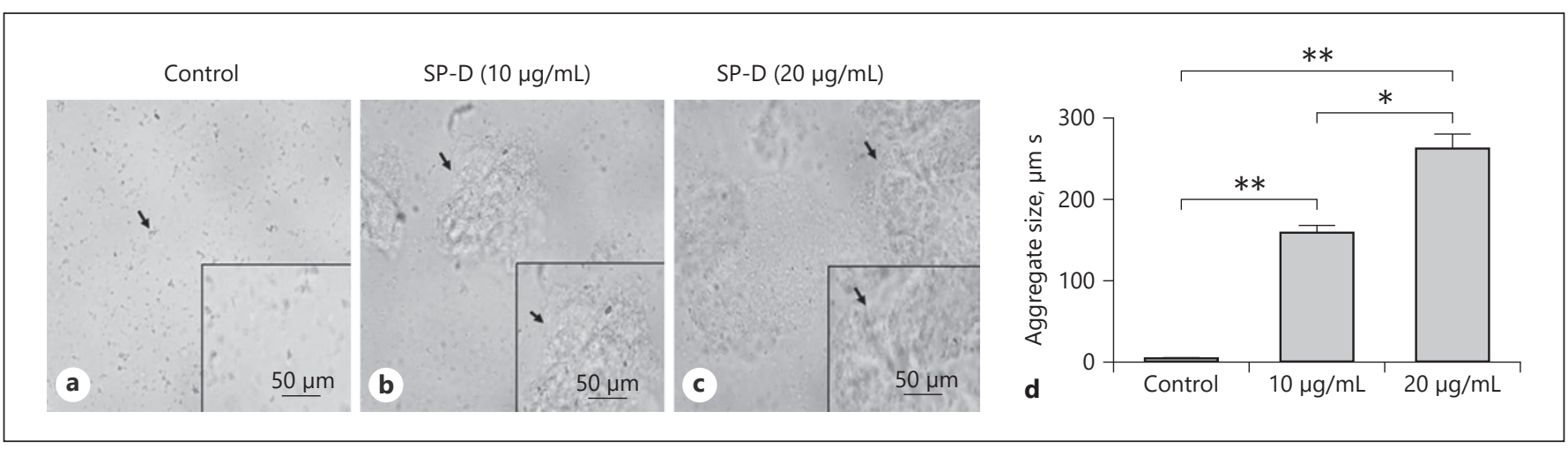

Fig. 5. SP-D-mediated NTHi bacterial aggregation: pure SP-D at concentrations of 10 and $20 \mu \mathrm{g} / \mathrm{mL}$ was added into NTHi bacterial solution in the presence of $2-\mu \mathrm{M} \mathrm{CaCl}_{2}$. The bacterial solution was incubated for $1 \mathrm{~h}$ at $37^{\circ} \mathrm{C}$; bacterial aggregation in the solution was examined under the microscope, and the difference in bacterial aggregation in different concentrations of SP-D was recorded.
Remarkably, bacterial aggregation was observed in the bacterial solution with SP-D protein but not in control without SP-D (a-c). Quantitative analysis of bacterial aggregates indicated a significant difference in the size of bacterial aggregates $(\mathbf{d}) .{ }^{*} p<0.05$ (the data from 3 independent experiments). SP-D, surfactant protein D; NTHi, nontypeable $H$. influenzae. rial aggregates were observed in the presence of SP-D at both 10 and $20 \mu \mathrm{g}$ of SP-D/mL condition but not in the absence of SP-D condition (Fig. 5). Moreover, the quantitative analysis of bacterial aggregates indicated a significant difference in the size of bacterial aggregates (Fig. 5d).

\section{Enhanced Bacterial Phagocytosis by Macrophages with SP-D Protein}

Alveolar macrophages were obtained from bronchoalveolar lavage prepared from SP-D KO mice. Alveolar macrophages were divided into 4 groups, that is, (1) only macrophages (control); (2) macrophages plus SP-D (5 $\mu \mathrm{g} / \mathrm{mL}) ;$ (3) macrophages plus cytochalasin $\mathrm{D}(2 \mu \mathrm{g} / \mathrm{mL})$; and (4) macrophages plus SP-D $(5 \mu \mathrm{g} / \mathrm{mL})$ and cytochalasin D $(5 \mu \mathrm{g} / \mathrm{mL})$. We mixed alveolar macrophages and NTHi strain bacterial suspension (final ratio 1:13 of cells to bacteria) in the presence of $5-\mu \mathrm{M} \mathrm{CaCl}{ }_{2}$ and then incubated for $30 \mathrm{~min}$ at room temperature. Slides were prepared for visualization of phagocytosis (Fig. 6a); then, the phagocytic index of macrophages was calculated for the 4 groups. The results indicated that the phagocytic index is higher in the group with SP-D protein $(p<0.01)$ compared to the other groups; cytochalasin $\mathrm{D}$ inhibited bacterial phagocytosis by macrophages (Fig. 6b). 


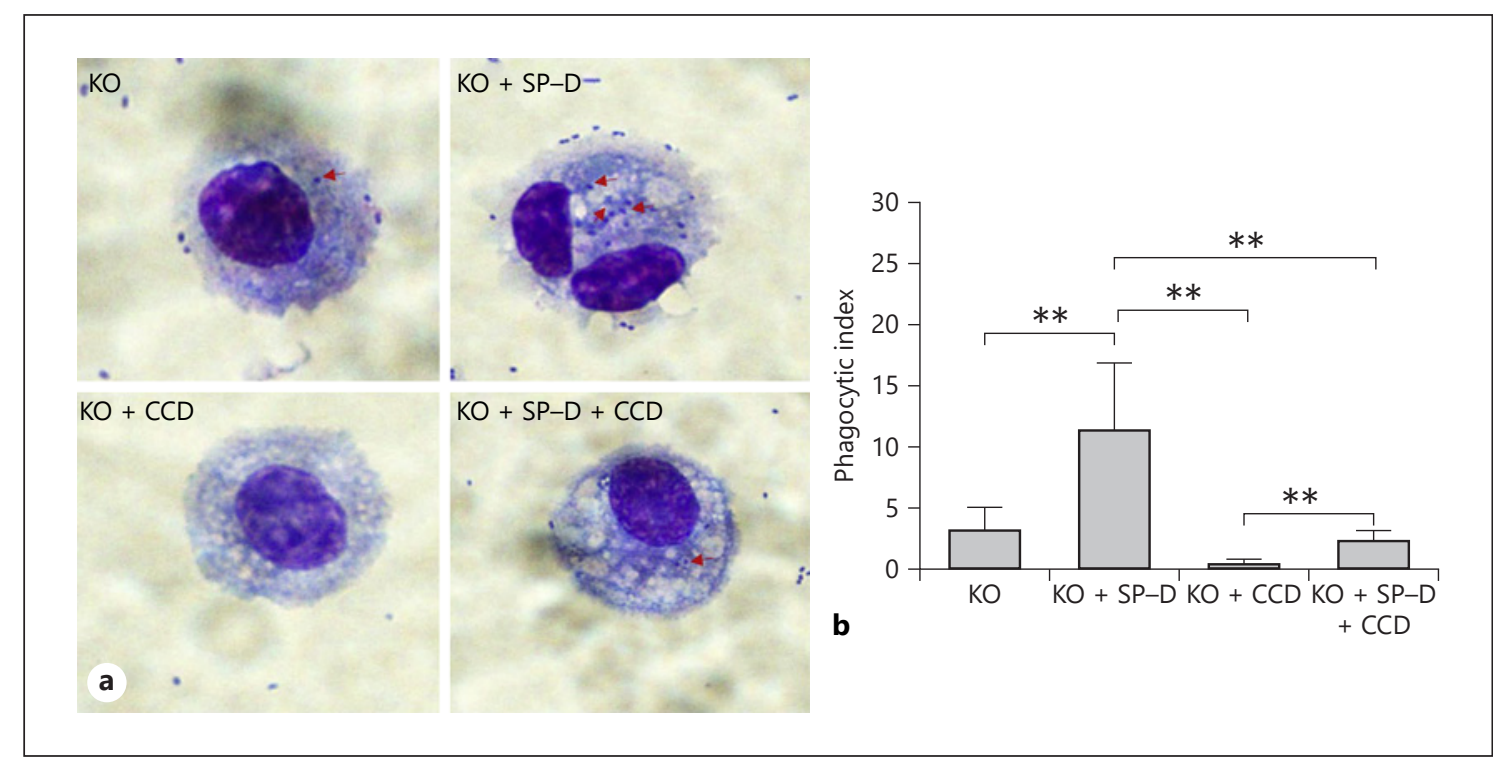

Fig. 6. SP-D-mediated enhanced bacterial phagocytosis by macrophages: we evaluated SP-D function in the phagocytosis by macrophages using an in vitro assay, in which alveolar macrophages from SP-D KO mice were isolated for the experiments. Experiments were performed with 4 groups, that is, (1) only macrophages (control); (2) macrophages plus SP-D ( $5 \mu \mathrm{g} / \mathrm{mL})$; (3) macrophages plus cytochalasin D (2 $\mu \mathrm{g} / \mathrm{mL})$; and (4) macrophages plus SP-D (5 $\mu \mathrm{g} / \mathrm{mL})$ and cytochalasin $\mathrm{D}(5 \mu \mathrm{g} / \mathrm{mL})$. Alveolar macrophages and NTHi strain bacterial suspension (final ratio 1:13 of cells to bacteria) were mixed in the presence of $5-\mu \mathrm{M} \mathrm{CaCl}_{2}$ and then incubated

\section{Increased Levels of Proinflammatory Cytokines in $S P-D K O$ than WT OM Mice}

We used the ELISA method to determine the concentrations of IL- $1 \beta$ and IL- 6 of MEWF at each time point in WT and SP-D KO OM mice as well as the controls (Fig. 7). The results showed that the IL-6 level increased significantly on day 1 post-NTHi infection compared with the control in both WT and SP-D KO mice. The level of IL-6 decreased over the third and seventh days, but there is a higher level of IL-6 in SP-D KO OM mice compared to WT OM mice at those time points (Fig. 7a). Similarly, the level of IL- $1 \beta$ increased significantly in days 1 and $3 \mathrm{com}$ pared with controls in SP-D KO OM mice but not in WT $\mathrm{KO}$ mice, and the decline of IL- $1 \beta$ was not significant until day 7 (Fig. 7b).

\section{Increased Level of NF- $\kappa B$ Activation in SP-D KO OM Mice than WT OM Mice}

Phosphorylated NF- $\kappa$ B p65 (p-NF- $\kappa$ B p65) as a marker of NF- $\kappa B$ signaling activation was examined using immunofluorescence staining with $\mathrm{Ab}$ specific to $\mathrm{p}-\mathrm{NF}-\kappa \mathrm{B}$ p65 (Fig. 8). The positive epithelial cells with p-NF-кB for $30 \mathrm{~min}$ at room temperature. After incubation, the cells were washed with saline and mounted on the slides by using the cytospin method (a). Phagocytic bacteria were counted, and the phagocytic index was calculated. The results showed that the phagocytic index is the highest in the KO + SP-D group among the 4 groups $\left({ }^{* *} p<0.01\right)$. Cytochalasin $\mathrm{D}$ inhibited bacterial phagocytosis by macrophages $\left(\mathrm{KO}+\mathrm{SP}-\mathrm{D}>\mathrm{KO}+\mathrm{SP}-\mathrm{D}+\mathrm{CCD}\left({ }^{* *} p<0.01\right)(\mathbf{b})\right.$. The experiments were repeated 3 times. Original magnifications, $\times 1,000$. SP-D, surfactant protein D; NTHi, nontypeable $H$. influenzae; $\mathrm{KO}$, knockout.

p65 Ab and total epithelial cells were analyzed at 200x using a fluorescence Eclipse TE2000-U microscope (Nikon, Tokyo, Japan). The results showed an increased number of p-NF- $\kappa \mathrm{B}$ p650-positive cells in the ME epithelial cells on day 1 in infected WT and SP-D KO mice compared to controls (Fig. 8a, b), suggesting increased NF- $\kappa \mathrm{B}$ signaling activation in the ME after NTHi infection. Further analysis indicated that SP-D KO mice had significantly higher levels of NF- $\kappa \mathrm{B}$ signaling activation on days 3 and 7 compared to WT mice (Fig. 8b). To further confirm the results obtained from immunofluorescence assay, a semiquantitative analysis of NF- $\mathrm{kB} 1 \mathrm{mRNA}$ expression in the ME tissues was performed by using RT-PCR as described previously [34]. The results showed similar patterns of NF- $\kappa$ B1 mRNA and protein in the ME tissues of infected mice (Fig. 8c, d).

\section{Higher NLRP3 Activation in SP-D KO OM Mice than WT OM Mice}

To determine the effect of SP-D on NLRP3 inflammasome activations in the ME and ET tissues of OM mice, immunofluorescence analyses with an anti-NLRP3 anti- 


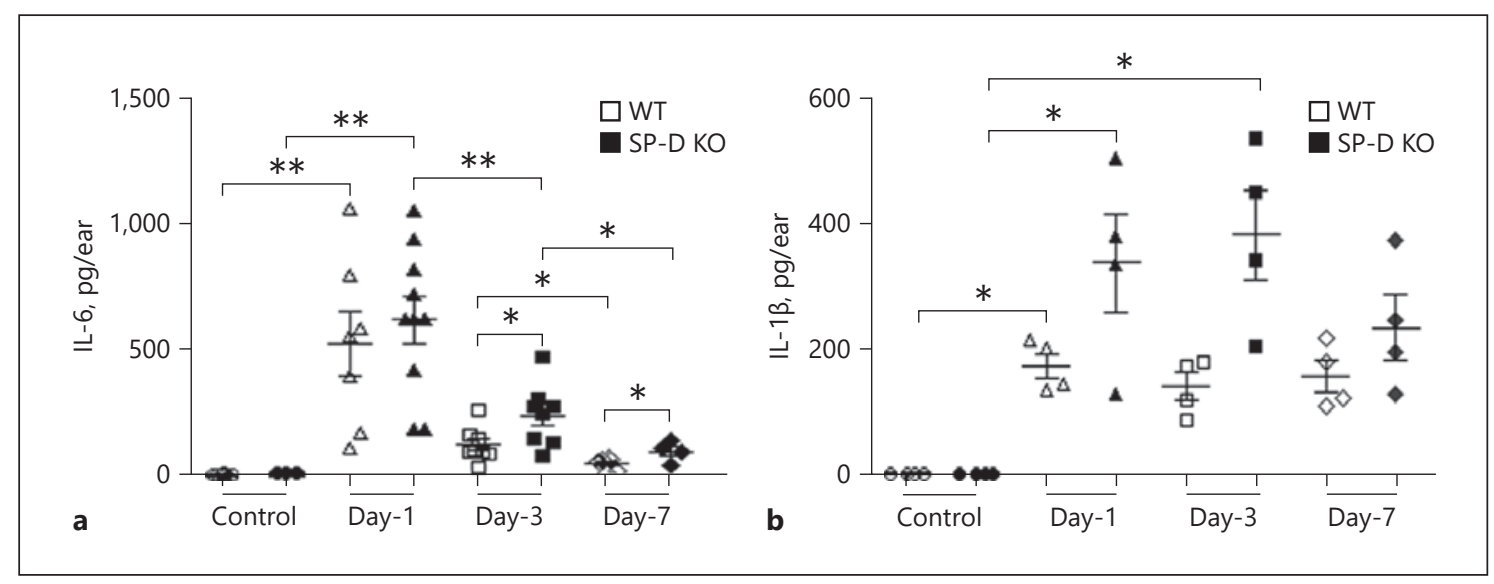

Fig. 7. Expression of proinflammatory cytokines in WT and SP-D $\mathrm{KO}$ mice: levels of proinflammatory cytokines in middle ear wash during acute OM and control mice. a IL-6 showed a significant increase in infected WT and SP-D KO mice compared to the controls. The level of IL- 6 on day 1 is the highest at the 3 time points. The IL- 6 levels on days 3 and 7 were significantly higher in infected SP-D KO mice than infected WT mice $(p<0.05)$. b IL- $1 \beta$ level showed a significant increase in infected WT and SP-D KO mice compared to the controls. The level of IL-1 $\beta$ on days 1 and 3 in infected SP-D KO mice were higher than that of infected WT mice. Cytokines were determined by enzyme-linked immunosorbent assay. ${ }^{*} p<0.05$ and ${ }^{* *} p<0.01$. Data are represented as means \pm SEM ( $n=5 \mathrm{mice} /$ group/time point). SP-D, surfactant protein D; OT, otitis media; WT, wild type; KO, knockout.
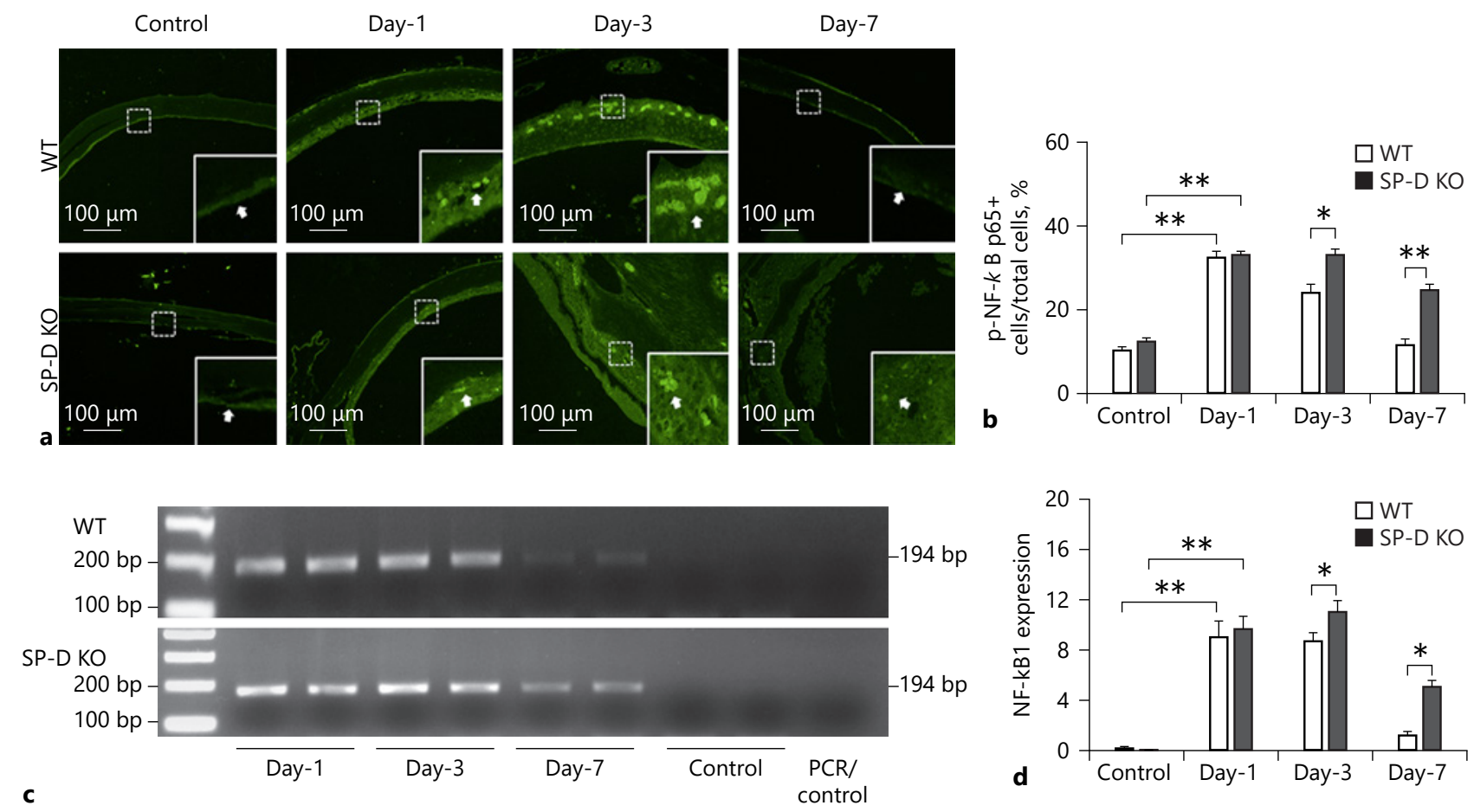

Fig. 8. Increased NF- $\kappa \mathrm{B}$ activation in the SP-D KO mice compared to WT mice. Phosphorylated NF- $\kappa \mathrm{B}$ expression in ME mucosa: anti-phosphorylated-NF- $\kappa \mathrm{B}$ p $65 \mathrm{Ab}$ was used to detect activated and translocated NF- $\kappa B$ levels (a). Based on the IF analysis, there is a significant increase in $\mathrm{p}-\mathrm{NF}-\kappa \mathrm{B}$ p 65 in ME mucosa on day $1 \mathrm{com}-$ pared to controls in both SP-D KO and WT mice. The level of
p-NF- $\kappa$ B p65 increased significantly on days 3 and 7 in infected SP-D KO compared to infected WT mice (b). Similar patterns of NF- $\kappa$ B1 mRNA expression in the ME tissues of infected WT and SP-D KO mice were detected (c, d). ${ }^{*} p<0.05$ and ${ }^{* *} p<0.01(n=4$ mice/group/time point). NF- $\kappa \mathrm{B}$, nuclear factor kappa B; SP-D, surfactant protein $\mathrm{D} ; \mathrm{ME}$, middle ear; WT, wild type; $\mathrm{KO}$, knockout. 


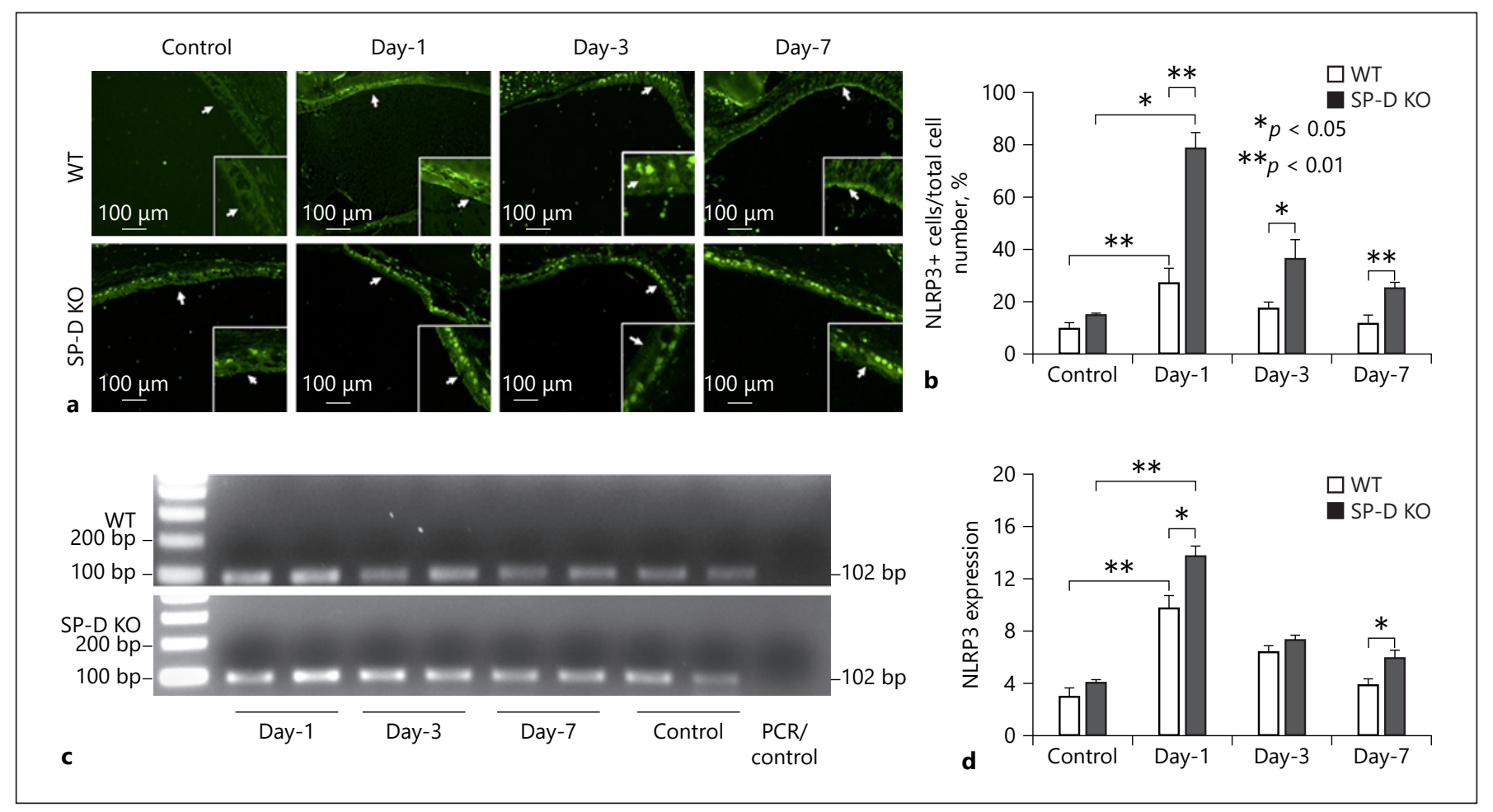

Fig. 9. NLRP3 activation in WT and SP-D KO mice: immunofluorescence was used to detect NLRP3 activation in ME mucosa from control and the different time points of NTHi-induced OM in SP-D KO and WT mice. The results show that NLRP3 activity was significantly higher in days 1 and 3 compared to control in both genotypes (a). NLRP3 activity was also significantly higher in SP-D

body was carried out in this study. As shown in Figure 9, increased NLRP3 IF positive cells were detected in the OM mice compared to the controls, and different levels of NLRP3 inflammasome activation were observed between WT and SP-D KO mice, that is, SP-D KO mice had significantly more positive cells compared to WT mice on days 1 and $7(p<0.01)$ (Fig. 9a, b). Semiquantitative analysis of NLRP3 mRNA expression in the ME tissues was performed by using RT-PCR. The results showed similar patterns between NLRP3 mRNA and protein in the ME tissues of infected mice (Fig. 9c, d).

\section{Increased NLRP3 Activation and SP-D Expression in}

HMEEC-1 Cells after LPS Exposure

In order to confirm NLRP3 inflammasome activation in the ME epithelial cells in the OM model, we used in vitro cultured HMEEC-1 cells and treated cells with LPS challenge from 0 to $50 \mu \mathrm{g} / \mathrm{mL}$ of LPS. We observed a higher level of NLRP3 activation in the HMEEC- 1 cells $(p<$ 0.05 ) after the LPS challenge, and the level of NLRP3 ac-
KO than in WT mice across all time points (b). Similar patterns of NLRP3 mRNA expression in the ME tissues of infected WT and SP-D KO mice were detected (c, d). ${ }^{*} p<0.05$ and ${ }^{* *} p<0.01(n=$ 4 mice per group). SP-D, surfactant protein D; OT, otitis media; $\mathrm{ME}$, middle ear; WT, wild type; KO, knockout.

tivation was in an LPS dose-independent manner (Fig. 10), indicating the HMEEC-1 cells have an inflammatory response to LPS treatment and confirming our observation in the in vivo data (see Fig. 8). Furthermore, we also examined the expression of SP-D in the HMEEC-1 cells after the LPS challenge. The results indicate increased expression of SP-D in HMEEC-1 cells after LPS challenge and in an LPS dose-dependent manner (Fig. 10).

\section{Discussion}

$\mathrm{OM}$ is the most common childhood illness affecting around $80 \%$ of children before the age of 3 . It is also the most typical reason for antibiotic prescription and surgery in young children [36]. OM is mostly a self-limited illness that usually resolves within a week or so, but in a subset of patients, it tends to either recur many times or progress to a chronic condition that leads to hearing impairment and other complications that range from chron- 

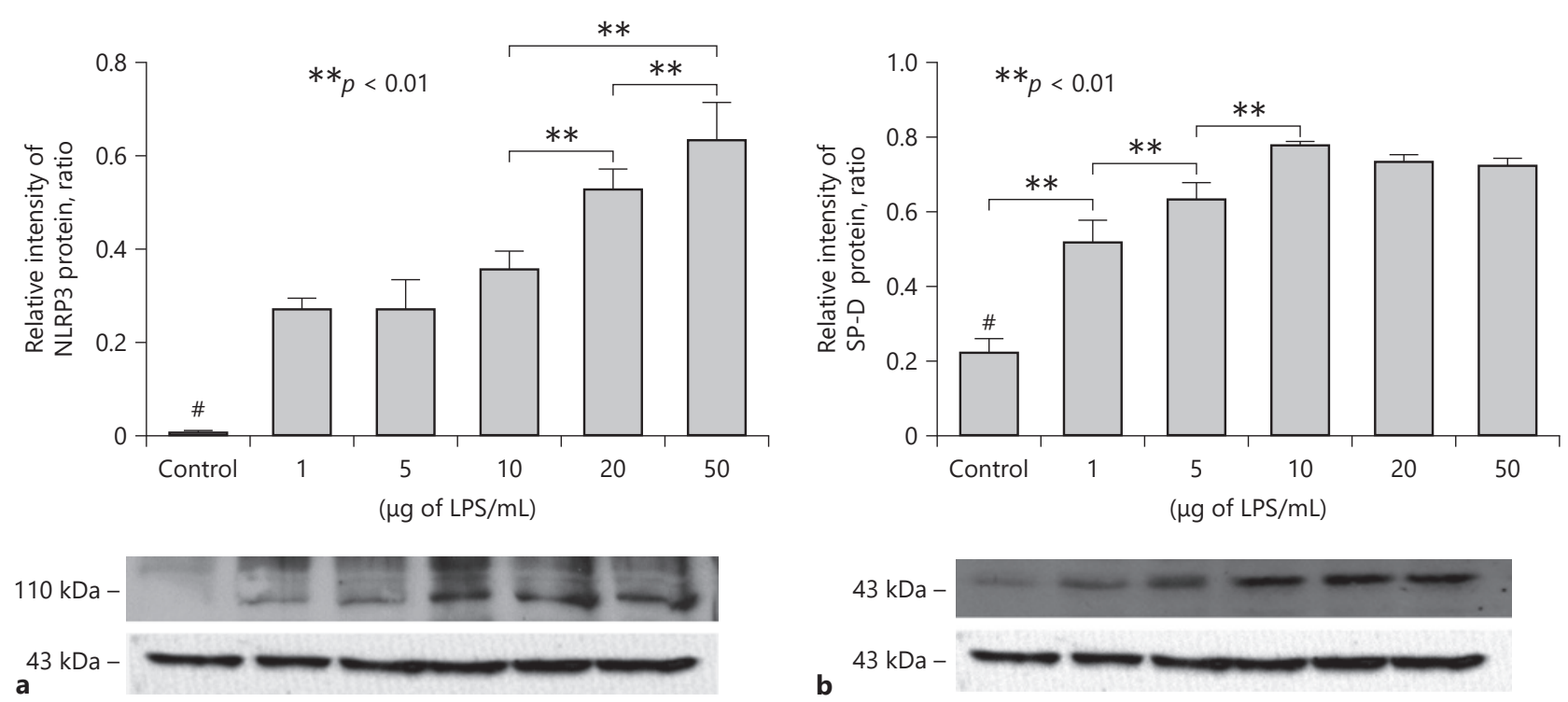

Fig. 10. NLRP3 activation and SP-D expression in HMEEC-1 cells after LPS exposure: to detect NLRP3 inflammasome activation in the HMEEC-1, we treated HMEEC-1 cells with LPS in doses from 0 to $50 \mu \mathrm{g} / \mathrm{mL}$. We observed a higher level of NLRP3 activation in the HMEEC- 1 cells $(\# p<0.05)$ after the LPS challenge; the level of NLRP3 activation was increased in a dose-dependent manner (a), indicating the HMEEC-1 cells have an inflammatory response to

LPS treatment and confirm our observation in the in vivo data. We also examined SP-D expression in the HMEEC-1 cells after LPS challenge $(\# p<0.05)$. The results indicate increased expression of SP-D in HMEEC-1 cells after LPS challenge and in an LPS dosedependent manner $(\mathbf{b}) .{ }^{* *} p<0.01$ (the data from 3 independent experiments). HMEEC-1, human middle ear epithelial cell line; SP-D, surfactant protein D; LPS, lipopolysaccharide.

ic ear discharge to life-threatening illness such as brain abscess or meningitis [37-39]. The innate immune system plays an essential role in defending against organisms, causing $\mathrm{OM}$ as it often occurs at an early age at which adaptive immunity is not fully developed. Pattern recognition receptors (PRRs) are important elements of the innate immune system that help in recognizing pathogen-associated molecular patterns and in the elimination of the offending agents. PRRs induce the release and activation of cytokines to facilitate a series of immune responses leading to the resolution of infection [40]. SP-A and SP-D belong to C-type lectins, which function as PRRs and are important in host defense and regulation of inflammation in the lung. Few studies, including our recent SP-A study [32] on the immune response to OM, exist. To the best of our knowledge, no research was carried out for the role of SP-D in OM. In this study, we have investigated the role of SP-D in OM using in vivo and in vitro approaches.

In the present study, we have found that SP-D is expressed in the mouse ME and ET mucosa, which confirms the previous observation of other studies that found SP-D

expressed in porcine ET epithelium [32, 41]. Furthermore, we found that the lack of SP-D could lead to an increase in the inflammatory response to NTHi-induced $\mathrm{ME}$ infection and to delay $\mathrm{OM}$ resolution as compared to WT mice. The proliferative response of the mouse ME mucosa following bacterial infection has been extensively documented [42]. At this point, the mucosa has developed into a pseudocolumnar epithelium containing secretory and ciliated cells, underlain by a highly organized stroma. The mucosa then gradually recovers as the infection is resolved, returning to its normal thickness by $5-7$ days [43]. Other innate immunity-related genes have also been found to play a role in the delayed resolution of OM in mice. For instance, Toll-like receptor 9 (TLR-9) KO mice exhibited modestly, but significantly, greater thickness of the ME mucosa prior to NTHi administration, compared to WT mice. However, in contrast to WT mice, NTHi induced no significant increase in mucosal thickness for the first 3 days after inoculation in the TLR-9 KO mice, but thickness increased from days 5-14, with recovery not complete at the longest postinoculation time point examined [44]. These indicate that innate immune 
system plays a critical role in the pathogenesis of $\mathrm{OM}$ and disease resolution.

SP-D plays an important role in host defense by preventing the dissemination of microbes through agglutination and growth inhibition and killing. It also promotes bacterial clearance through enhancing phagocytosis and by interacting with other PRRs such as TLRs and TLRassociated molecules to regulate inflammatory response $[45,46]$. Our results of this study show that SP-D agglutinated NTHi in the presence of calcium, which confirms previous studies that show SP-D agglutination of Gramnegative bacteria [30,47]. SP-D has been shown to interact with a number of bacteria directly, including Pseudomonas aeruginosa, S. pneumoniae, Escherichia coli, and Mycobacterium tuberculosis, leading to several physiologically relevant processes associated with bacterial clearance, including agglutination, phagocytosis, and growth inhibition [48]. SP-D $(10 \mu \mathrm{g} / \mathrm{mL})$ can agglutinate FITClabeled GBS and $H$. influenzae in a calcium-dependent manner, but no agglutination was observed in the absence of calcium or SP-D [49].

We also found that SP-D significantly increases phagocytosis of NTHi, which confirms the results of other studies that show SP-D binds to alveolar macrophages and binds and increases macrophage association with E. coli, M. tuberculosis, and Pneumocystis carinii [48]. SP-D binds and increases phagocytosis of strains of $P$. aeruginosa without causing bacterial aggregation [49].

Previous studies with the specimen from OM patients demonstrated that 15 candidate genes in a population of families suffering from chronic $\mathrm{OM}$ with effusion (COME) or recurrent OM (ROM) were observed to be associated with SNPs in the mucin 5 region encompassing both MUC2 and MUC5AC/MUC5B, SFTPD (expressing SP-D protein), and TLR4 genes [50]. SFTPD polymorphisms in humans have been found to have an implication for SP-D protein assembly, function, and concentration [51] and are associated with severe respiratory syncytial virus infections in humans, which is a known precipitating factor for OM [52]. Furthermore, a genome-wide linkage scan indicated the susceptibility loci of OM with the 17q12 and 10q22 regions, where SP-A and SP-D genes are located [53].

SP-D can prevent the interaction of TLR2 and TLR4 with both smooth and rough LPS and thus inhibits both serotypes of LPS-induced TNF- $\alpha$ secretion from alveolar macrophages and NF- $\kappa \mathrm{B}$ activation in TLR4/MD-2-expressing HEK293 cells [54]. TLRs recognize molecular patterns associated with pathogens, such as bacteria and fungi. The interactions between TLRs and these molecu- lar patterns induce intracellular signaling pathways, such as the NF- $\kappa \mathrm{B}$ pathway, which in turn upregulate the expression of proinflammatory genes involved in the production of cytokines and chemokines and activation of the adaptive immune system. TLR deficiencies have been shown to be responsible for abnormalities in NTHi-induced OM pathogenesis and recovery [40]. Of these TLR family members, TLR2 is reported to regulate the pathogenesis of AOM with NTHi as it recognizes pathogenic patterns of NTHi and regulates the inflammatory responses of the host. Lipoprotein P6 of the NTHi uses TLR2 signaling to activate NF- $\kappa B$ in human epithelial cells [55]. TLR4 mediates LPS and lipooligosaccharide (LOS) responsiveness and recognizes Gram-negative bacteria via the LPS/LOS moiety present on the surfaces of these pathogens. Although the structure of LOS and LPS is different, lipid A, which is a common component to both, is thought to be responsible for TLR4 signaling, and LOS also induces TLR4 signaling [56]. LPS-TLR4 signaling and neutrophil NADPH oxidase activate NF- $\kappa B$ signaling and upregulate TLR2 expression in endothelial cells, and this increased TLR2 expression via NF- $\kappa B$ signaling results in increased ICAM-1 expression and enhanced neutrophil migration. TLR4 signaling appears to induce TLR2 expression, and TLR2 activation is critical for bacterial clearance and rapid resolution of OM [42]. Our results show that proinflammatory cytokines IL-6 and IL- $1 \beta$ significantly increased in the ME wash after 24 $\mathrm{h}$ from NTHi-induced OM in SP-D KO mice when compared to WT mice. In this study, we demonstrated a significant increase in phosphorylated NF- $\kappa \mathrm{B}$ (p65) in ME mucosa of infected WT and SP-D KO mice on day $1 \mathrm{com}-$ pared to controls, which decreased significantly in infected WT on days 3 and 7 in comparison to infected SP-D $\mathrm{KO}$ mice which remain higher in both time points. These results are consistent with our recent findings that the presence of SP-D in WT mice is able to significantly reduce the activation of NLRP3 inflammasome and p-NFkB p65 in acute lung injury (ALI) [57]. Kurabi et al. [40] showed a rapid and dramatic increase in IL- $1 \beta$ gene expression after NTHi inoculation between time point $3 \mathrm{~h}$ and 3 days that peaks to over 70 -fold induction at $24 \mathrm{~h}$. IL- $1 \beta$ has been implicated as being crucial to the immune responses of several pathogens and is strongly regulated at the transcriptional level.

NLRP3 inflammasome activation leads to the activation of procaspase- 1 , which cleaves pro-IL- $1 \beta$ to its active form. Cleaved IL- $1 \beta$ has been shown to not only contribute to innate immunity but also to aid in the modulation of immune responses and pathogen clearance [40]. In a 
study of a mouse model of severe acute pancreatitis (SAP), SAP induced ALI; in our recent report, we concluded that SP-D exerts protective effects against ALI via suppressing NLRP3 inflammasome and NF- $\mathrm{KB}$ activation in experimental SAP [57].

In summary, innate immunity is important in the ME response to various infectious conditions. SP-D plays an important role in the innate immunity of the lung and other extrapulmonary tissues/organs. The results from this study demonstrate SP-D probably plays a similar role in the ME. SP-D enhances bacterial clearance by increasing bacterial agglutination and phagocytosis. SP-D modulates innate immune and inflammatory response in the $\mathrm{ME}$ of NTHi-induced OM in mice and improves disease resolution through regulation of NF- $\mathrm{KB}$ and NLRP3-associated inflammasome activation, which suggest SP-D as a potential therapeutic agent in OM.

\section{Acknowledgements}

The authors thank Dr. S. Hawgood of the University of California, San Francisco, CA, for kindly providing SP-D KO mice. They also thank all members of Profs. Cooney's and Nieman's laboratories for the kind support to this project. This study was supported in part by NIH R01HL136706, National Science Foundation (NSF) research award (1722630) (to G.W.), and one grant from Clark Endowment for Pediatric Research Fund (to G.W.).

\section{Statement of Ethics}

All animal experiments and protocols were conducted in accordance with the guidelines of the Institutional Animal Care and Use Committee (IACUC), SUNY Upstate Medical University, National Institutes of Health guidelines on the use of laboratory animals, and those of "ARRIVE" on the use of laboratory animals.

\section{Conflict of Interest Statement}

The authors have no relevant conflicts of interest.

\section{Funding Sources}

The authors disclosed receipt of the following financial support for the research, authorship, and/or publication of this article: this study was supported in part by NIH R01HL136706, NSF research award (1722630), and one grant from Clark Endowment for Pediatric Research Fund (G.W.).

\section{Author Contributions}

O.A. performed experiments, analyzed data, interpreted results, and drafted the manuscript. T.L., X.C., Q.W., and G.V. performed some experiments. G.W. conceived the study and designed experiments, interpreted results, and wrote the manuscript.

\section{References}

1 Qureishi A, Lee Y, Belfield K, Birchall JP, Daniel M. Update on otitis media: prevention and treatment. Infect Drug Resist. 2014 Jan 10;7:15-24.

2 Vermee Q, Cohen R, Hays C, Varon E, Bonacorsi S, Bechet S, et al. Biofilm production by Haemophilus influenzae and Streptococcus pneumoniae isolated from the nasopharynx of children with acute otitis media. BMC Infect Dis. 2019 Jan 11;19(1):44.

3 Ryan AF, Ebmeyer J, Furukawa M, Pak K, Melhus A, Wasserman SI, et al. Mouse models of induced otitis media. Brain Res. 2006 May 26;1091(1):3-8.

4 Kostic M, Ribaric Jankes K, Trotic R, Ries M, Ledic B, Bedekovic V. Clinical and audiological findings in children with acute otitis media. Acta Otolaryngol. 2015 Jul;135(7):64550.

5 Pitaro J, Waissbluth S, Quintal MC, Abela A, Lapointe A. Characteristics of children with refractory acute otitis media treated at the pediatric emergency department. Int J Pediatr Otorhinolaryngol. 2019 Jan;116:173-6.

6 Pettigrew MM, Gent JF, Zhu Y, Triche EW, Belanger KD, Holford TR, et al. Association of surfactant protein A polymorphisms with otitis media in infants at risk for asthma. BMC Med Genet. 2006 Aug 2;7:68.

7 Monasta L, Ronfani L, Marchetti F, Montico M, Vecchi Brumatti L, Bavcar A, et al. Burden of disease caused by otitis media: systematic review and global estimates. PLoS One. 2012; 7(4):e36226.

8 Mittal R, Kodiyan J, Gerring R, Mathee K, Li JD, Grati M, et al. Role of innate immunity in the pathogenesis of otitis media. Int J Infect Dis. 2014 Dec;29:259-67.

9 Leibovitz E, Serebro M, Givon-Lavi N, Greenberg D, Broides A, Leiberman A, et al. Epidemiologic and microbiologic characteristics of culture-positive spontaneous otorrhea in children with acute otitis media. Pediatr Infect Dis J. 2009 May;28(5):381-4.

10 Coker TR, Chan LS, Newberry SJ, Limbos MA, Suttorp MJ, Shekelle PG, et al. Diagnosis, microbial epidemiology, and antibiotic treatment of acute otitis media in children: a systematic review. JAMA. 2010 Nov 17;304(19): 2161-9.

11 Val S, Krueger A, Poley M, Cohen A, Brown K, Panigrahi A, et al. Nontypeable Haemophilus influenzae lysates increase heterogeneous nuclear ribonucleoprotein secretion and exo- some release in human middle-ear epithelial cells. FASEB J. 2018 Apr;32(4):1855-67.

12 Hu F, Ding G, Zhang Z, Gatto LA, Hawgood $S$, Poulain FR, et al. Innate immunity of surfactant proteins $A$ and $D$ in urinary tract infection with uropathogenic Escherichia coli. Innate Immun. 2016 Jan;22(1):9-20.

13 Mulay A, Akram KM, Williams D, Armes H, Russell C, Hood D, et al. An in vitro model of murine middle ear epithelium. Dis Model Mech. 2016 Nov 1;9(11):1405-17.

14 Chun YM, Moon SK, Lee HY, Webster P, Brackmann DE, Rhim JS, et al. Immortalization of normal adult human middle ear epithelial cells using a retrovirus containing the E6/E7 genes of human papillomavirus type 16. Ann Otol Rhinol Laryngol. 2002 Jun; 111(6):507-17.

15 Kariya S, Okano M, Zhao P, Maeda Y, Kataoka $Y$, Higaki T, et al. NLRP3 inflammasome expression in lipopolysaccharide-induced otitis media. Acta Otolaryngol. 2018 Dec;138(12):1061-5.

16 Li L, Guo X, Olszewski E, Fan Z, Ai Y, Han Y, et al. Expression of surfactant protein-A during LPS-induced otitis media with effusion in mice. Otolaryngol Head Neck Surg. 2015 Sep; 153(3):433-9. 
17 Hasegawa Y, Takahashi M, Ariki S, Saito A, Uehara Y, Takamiya R, et al. Surfactant protein A down-regulates epidermal growth factor receptor by mechanisms different from those of surfactant protein D. J Biol Chem. 2017 Nov 10;292(45):18565-76.

18 Botas C, Poulain F, Akiyama J, Brown C, Allen L, Goerke J, et al. Altered surfactant homeostasis and alveolar type II cell morphology in mice lacking surfactant protein D. Proc Natl Acad Sci U S A. 1998 Sep 29;95(20): 11869-74.

19 Clark H, Palaniyar N, Strong P, Edmondson J, Hawgood S, Reid KB. Surfactant protein D reduces alveolar macrophage apoptosis in vivo. J Immunol. 2002 Sep 15;169(6):2892-9.

20 Ujma S, Horsnell WG, Katz AA, Clark HW, Schäfer G. Non-pulmonary immune functions of surfactant proteins A and D. J Innate Immun. 2017;9(1):3-11.

21 Sorensen GL. Surfactant protein D in respiratory and non-respiratory diseases. Front Med. 2018;5:18.

22 Floros J, Fan R, Matthews A, DiAngelo S, Luo $\mathrm{J}$, Nielsen H, et al. Family-based transmission disequilibrium test (TDT) and case-control association studies reveal surfactant protein $\mathrm{A}$ (SP-A) susceptibility alleles for respiratory distress syndrome (RDS) and possible race differences. Clin Genet. 2001 Sep;60(3):17887.

23 McGuire JF. Surfactant in the middle ear and eustachian tube: a review. Int J Pediatr Otorhinolaryngol. 2002 Oct 21;66(1):1-15.

24 Kurabi A, Pak K, Ryan AF, Wasserman SI. Innate immunity: orchestrating inflammation and resolution of otitis media. Curr Allergy Asthma Rep. 2016 Jan;16(1):6.

25 McNeely TB, Coonrod JD. Aggregation and opsonization of type A but not type B Hemophilus influenzae by surfactant protein A. Am J Respir Cell Mol Biol. 1994 Jul;11(1): $114-22$.

26 Malhotra R, Lu J, Holmskov U, Sim RB. Collectins, collectin receptors and the lectin pathway of complement activation. Clin Exp Immunol. 1994 Aug;97(Suppl 2):4-9.

27 Eggleton P, Reid KB. Lung surfactant proteins involved in innate immunity. Curr Opin Immunol. 1999 Feb;11(1):28-33.

28 Konishi M, Nishitani C, Mitsuzawa H, Shimizu T, Sano H, Harimaya A, et al. Alloiococcus otitidis is a ligand for collectins and Tolllike receptor 2 , and its phagocytosis is enhanced by collectins. Eur J Immunol. 2006 Jun;36(6):1527-36.

29 Lim DJ, Chun YM, Lee HY, Moon SK, Chang $\mathrm{KH}, \mathrm{Li}$ JD, et al. Cell biology of tubotympanum in relation to pathogenesis of otitis media: a review. Vaccine. 2000 Dec 8;19(Suppl 1):S17-25.

$30 \mathrm{Wu} \mathrm{H}$, Kuzmenko A, Wan S, Schaffer L, Weiss A, Fisher JH, et al. Surfactant proteins $A$ and $D$ inhibit the growth of Gram-negative bacteria by increasing membrane permeability. J Clin Invest. 2003 May;111(10):1589602 .
31 Park K, Lim DJ. Luminal development of the Eustachian tube and middle ear: murine model. Yonsei Med J. 1992 Jun;33(2):159-67.

32 Abdel-Razek O, Ni L, Yang F, Wang G. Innate immunity of surfactant protein A in experimental otitis media. Innate Immun. 2019 Oct; 25(7):391-400.

33 Kariya S, Schachern PA, Cureoglu S, Tsuprun V, Okano M, Nishizaki K, et al. Up-regulation of macrophage migration inhibitory factor induced by endotoxin in experimental otitis media with effusion in mice. Acta Otolaryngol. 2008 Jul;128(7):750-5.

34 Yamamoto H, Omelchenko I, Shi X, Nuttall AL. The influence of NF-kappaB signal-transduction pathways on the murine inner ear by acoustic overstimulation. J Neurosci Res. 2009 Jun;87(8):1832-40.

35 Wang X, Gong P, Zhang X, Wang J, Tai L, Wang $X$, et al. NLRP3 inflammasome activation in murine macrophages caused by Neospora caninum infection. Parasit Vectors. 2017 May 30;10(1):266.

36 Coticchia JM, Chen M, Sachdeva L, Mutchnick S. New paradigms in the pathogenesis of otitis media in children. Front Pediatr. 2013 Dec 23;1:52.

37 Cassano P, Ciprandi G, Passali D. Acute mastoiditis in children. Acta Biomed. 2020 Feb 17; 91(1-S):54-9.

38 Danishyar A, Ashurst JV. Acute otitis media. Treasure Island, FL: StatPearls; 2020.

39 Krishnan M, Walijee H, Jesurasa A, De S, Sinha A, Sharma R, et al. Clinical outcomes of intracranial complications secondary to acute mastoiditis: the Alder Hey experience. Int J Pediatr Otorhinolaryngol. 2020 Jan; 128: 109675.

40 Kurabi A, Lee J, Wong C, Pak K, Hoffman $\mathrm{HM}$, Ryan AF, et al. The inflammasome adaptor ASC contributes to multiple innate immune processes in the resolution of otitis media. Innate Immun. $2015 \mathrm{Feb}$;21(2):203-14.

41 Paananen R, Glumoff V, Hallman M. Surfactant protein $\mathrm{A}$ and $\mathrm{D}$ expression in the porcine Eustachian tube. FEBS Lett. 1999 Jun 11; 452(3):141-4.

42 Leichtle A, Hernandez M, Pak K, Yamasaki K, Cheng CF, Webster NJ, et al. TLR4-mediated induction of TLR2 signaling is critical in the pathogenesis and resolution of otitis media. Innate Immun. 2009 Aug;15(4):205-15.

43 Cho CG, Pak K, Webster N, Kurabi A, Ryan AF. Both canonical and non-canonical NF- $k B$ activation contribute to the proliferative response of the middle ear mucosa during bacterial infection. Innate Immun. 2016 Nov; 22(8):626-34.

44 Leichtle A, Hernandez M, Lee J, Pak K, Webster NJ, Wollenberg B, et al. The role of DNA sensing and innate immune receptor TLR9 in otitis media. Innate Immun. $2012 \mathrm{Feb}$;18(1): 3-13.

45 Ariki S, Nishitani C, Kuroki Y. Diverse functions of pulmonary collectins in host defense of the lung. J Biomed Biotechnol. 2012;2012: 532071.
46 Casals C, Campanero-Rhodes MA, GarcíaFojeda B, Solís D. The role of collectins and galectins in lung innate immune defense. Front Immunol. 2018;9:1998.

47 Kuan SF, Rust K, Crouch E. Interactions of surfactant protein $\mathrm{D}$ with bacterial lipopolysaccharides. Surfactant protein D is an Escherichia coli-binding protein in bronchoalveolar lavage. J Clin Invest. 1992 Jul;90(1):97106.

48 Soltysiak KA, van Schaik EJ, Samuel JE. Surfactant protein D binds to Coxiella burnetii and results in a decrease in interactions with murine alveolar macrophages. PLoS One. 2015;10(9):e0136699.

49 LeVine AM, Whitsett JA, Gwozdz JA, Richardson TR, Fisher JH, Burhans MS, et al. Distinct effects of surfactant protein A or D deficiency during bacterial infection on the lung. J Immunol. 2000 Oct 01;165(7):3934-40.

50 Sale MM, Chen WM, Weeks DE, Mychaleckyj JC, Hou X, Marion M, et al. Evaluation of 15 functional candidate genes for association with chronic otitis media with effusion and/ or recurrent otitis media (COME/ROM). PLoS One. 2011;6(8):e22297.

51 Leth-Larsen R, Garred P, Jensenius H, Meschi J, Hartshorn K, Madsen J, et al. A common polymorphism in the SFTPD gene influences assembly, function, and concentration of surfactant protein D. J Immunol. 2005 Feb 1; 174(3):1532-8.

52 Ampuero S, Luchsinger V, Tapia L, Palomino MA, Larrañaga CE. SP-A1, SP-A2 and SP-D gene polymorphisms in severe acute respiratory syncytial infection in Chilean infants. Infect Genet Evol. 2011 Aug;11(6):1368-77.

53 Casselbrant ML, Mandel EM, Jung J, Ferrell RE, Tekely K, Szatkiewicz JP, et al. Otitis media: a genome-wide linkage scan with evidence of susceptibility loci within the $17 \mathrm{q} 12$ and 10q22.3 regions. BMC Med Genet. 2009 Sep 3;10:85.

54 Yamazoe M, Nishitani C, Takahashi M, Katoh T, Ariki S, Shimizu T, et al. Pulmonary surfactant protein D inhibits lipopolysaccharide (LPS)-induced inflammatory cell responses by altering LPS binding to its receptors. J Biol Chem. 2008 Dec 19;283(51):35878-88.

55 Shuto T, Xu H, Wang B, Han J, Kai H, Gu XX, et al. Activation of NF-kappa B by nontypeable Hemophilus influenzae is mediated by toll-like receptor 2-TAK1-dependent NIKIKKalpha /beta-I kappa B alpha and MKK3/6p38 MAP kinase signaling pathways in epithelial cells. Proc Natl Acad Sci U S A. 2001 Jul 17;98(15):8774-9.

56 Hirano T, Kodama S, Fujita K, Maeda K, Suzuki M. Role of Toll-like receptor 4 in innate immune responses in a mouse model of acute otitis media. FEMS Immunol Med Microbiol. 2007 Feb;49(1):75-83.

$57 \mathrm{Yu} \mathrm{J}$, Ni L, Zhang X, Zhang J, Abdel-Razek O, Wang G. Surfactant protein D dampens lung injury by suppressing NLRP3 inflammasome activation and NF-kappaB signaling in acute pancreatitis. Shock. 2019 May;51(5):557-68. 